したが，全例とも術当日より意識の回復は良好であっ た. 術前より肝腎障害の高度な症例 3 を術後 18 日めに 多臓器不全にて失ったが, 他は, 最長 2.5 年, 平均 1.4 年の遠隔期の現在こくに問題はなく健在である.

\section{考察}

上行弓部に解離の及ぶ I 型解離性大動脈瘤に対する手 術術式は種々開発工夫されているが，満足すべきもので はなくとくに，“Inclusion 法”による置換グラフトー被 覆大動脈壁間の仮性動脈瘤発生に伴う再手術例の報告屯 散見され本術式の問題点も指摘されている ${ }^{1,2)}$. とくに大 動脈壁での被覆により縫合部の止血がおろそかになり, Marvasti ら 32 はその遠隔期において, 15 例中 4 例に吻 合部よりグラフトー被覆大動脈間への造影剂の“むれ”を 指摘し，また，Wekker ら"は同仮性動脈瘤部位への感 染による再手術例を報告している，われわれむ Bentall 手術後 4 年目の遠隔期において, 同部位のカンジダ症に より失った症例を経験した. したがって, Crawford ${ }^{5)}$, Kouchoukas $^{6)}$, Helseth ${ }^{7}$ らは, 大動脈瘤完全切除によ る，人工血管置換術を行い，とくに Helseth はその 7 年におよぶ経過観察にて，仮性動脈瘤の発生のないとと を報告している．われわれも，大動脈瘤手術において は, 瘤完全切除, 人工血管置換術を行っており, 今回の 5 症例においても, 大動脈瘤を完全切除し人工血管置換 術を行った.

弓部大動脈瘤および分枝遮断を要する手術において は，脳分離体外循環8)，超低体温下循環停止などの補助 手段を必要とするが，最近では，脳分離体外循環法が採
用されることが多い，しかしその至適灌流量および压に 関してまだ一定の見解を得ていない10 12). われわれの行 っている脳分離体外循環法は, その適正灌流量の指標之 して, 脳分離体外循環開始直前の体血圧值を左右浅側頭 動脈圧の目標值として，その值を維持するように流量 を調節している. 5 症例の送血流量は右腋下動脈が平 均 $316 \mathrm{ml} / \mathrm{min}$, 左総頸動脈が $233 \mathrm{ml} / \mathrm{min}$ であり, そ のときの左右浅側頭動脈王は $32 \sim 73 \mathrm{mmHg}$, 平均 43.7 $\mathrm{mmHg}$ に維持された. 術後は意識の回復む良好で, わ れわれの脳分離体外循環法の妥当性を確認した。

結語

1）急性 I 型解離性大動脈瘤の 5 症例に対して, 脳分 離体外循環併用下に上行弓部完全切除による, 主要 3 分 枝再建を含む上行弓部人工血管置換術を行い，良好な結 果を得たので報告した。

2）脸分離体外循環において，至適灌流量の指標とし て，脳分離体外循環開始前の体血圧值を左右浅側頭動脈 圧の目標值として流量を調節することは，妥当であるこ とが示された.

文 献 1) 䨦木 等ほ加：日胸外会誌 $36: 149,1988,2)$ Kouchoukas, N. T.: J. T.C.S. 96: 967, 1988. 3) Marvasti, M. A. et al.: J. T. C. S. $95:$ 924, 1988. 4) Wekker, P.B. et al.: J. T.C.S. 88: 447, 1980. 5) Crawford, E.S. et al. Ann. Thorac. Surg. 40: 439, 1985. 6) Kouchuokas, N. T. et al.: J. T.C.S. 92: 671, 1986. 7) Helseth, H.K. et al.: J. T.C. S. 80: 754, 1980. 8) Soma, Y. et al.: Ann. Thorac. Surg. 34: 659, 1982.9 9) Sweeny, M. S. et al.: Ann. Thorac. Surg. 40：498，1985. 10) 田中二郎ほ加：日胸外会誌 32 : 1775, 1984. 11) 浅野献一ほか：胸部外科 $35: 343,1982$.

\title{
309 急性 A 型大動脈解離
}

一術前術後の大動脈造影の検討一

市立静岡病院 胸部心臟血管外科

大久保 憲 - 篠 崎 拓 島 本 光 臣上 野 陽一郎
吉 谷

急性 $\mathrm{A}$ 型大動脈解離の内科的治療の予後は不良であ り, 救命的外科治療の有効性が明らかにされてきた ${ }^{11}$. われわれの施設では急性 $\mathrm{A}$ 型大動脈解離に対し緊急大動
脈造影後可及的に緊急手術を行っている. 術前の迅速 な診断が求められるが，術後造影関する報告は少な $\left(^{22}\right.$. 自験例の術前術後の大動脈造影飞検討を加えた. 
表 1 急性A型大動脈解離緊急手術 15 術

\begin{tabular}{|c|c|c|c|c|c|}
\hline 症例 & 年齢 & 性 & 手 術 術 & 式 & 経 過期間 \\
\hline 1. & 52 & 男 & Entry 閉鎖 & & 3年 7 か月 \\
\hline 2. & 36 & 男 & 人工血管置換（中枢 3 層， & 末梢 3 層) & 3 年 3 加月 \\
\hline 3. & 39 & 男 & Bentall（末梢 3 層） & & 1 年 2 加月（死亡） \\
\hline 4. & 56 & 男 & $\begin{array}{l}\text { (1) 人工血管置換（中枢 } \\
\text { (2) 人工血管置換（中枢 }\end{array}$ & $\begin{array}{l}2 \text { 層, 末梢 } 2 \text { 層) } \\
3 \text { 層) }\end{array}$ & 2 年 8 加月 \\
\hline 5. & 55 & 男 & 人工血管置換（中枢 3 層, & 末梢 3 層) & 8加月 (死亡) \\
\hline 6. & 31 & 男 & 人工血管置換（中枢 3 層， & 末梢 3 層) & 2 年 6 加 \\
\hline 7. & 57 & 女 & 人工血管置換（中枢 3 層， & 末梢 3 層) & 2 年 5 加月 \\
\hline 8. & 44 & 男 & 人工血管置換（中枢 3 層， & 末梢 3 管) & 2 年 4 加月 \\
\hline 9. & 62 & 男 & 人工血管置換（中枢 2 層， & 末梢 2 層) & 1 年10加月 \\
\hline 10. & 31 & 女 & Bentall (末梢 2 層) & & 1 年 9 加月 \\
\hline 11. & 67 & 女 & 人工血管置換（中枢 3 層， & 末梢 2 層) & 9 分月 \\
\hline 12. & 67 & 女 & 人工血管置換（中枢 3 層， & 末梢 2 層) & 8 加月 \\
\hline 13. & 50 & 男 & 人工血管置換（中枢 2 層， & 末梢 2 層) & 6 加月 \\
\hline 14. & 75 & 男 & 人工血管置換（中枢 3 層， & 末梢 3 層) & 6 加月 \\
\hline 15. & 58 & 男 & 人工血管置換（中枢 3 層， & 末梢 3 層) & 5 加 \\
\hline
\end{tabular}

対 象

1985 年 10 月以降 89 年 4 月まで行った急性 A 型大動 脈解離手術は 15 例で, 内訳は男性 11 例, 女性 4 例 (31 75 歳, 平均 52 歳), 術前大動脈造影後緊急手術 を行った，全例上行大動脈江解離腔を有し，手術術式は Entry 閉鎖 1 例, 人工血管置換 11 例, 人工血管置換 + CABG 1 例, Bentall 2 例で, 人工血管吻合部は中枢 側 3 層フェルト補強を原則とし，末梢側は 3 層補強 8 例， 2 層補強 6 例，AR に対して Koster 様手術 ${ }^{3}$ を 行った，術後 2 層補強の中枢吻合部より新たな逆行解離 を生じた 1 例に， 3 層補強にて再手術を行った. 手術死 亡はなく，遠隔期に残存瘤破裂（ 1 年 2 名月), 脳血管 障害（8か月）にて各 1 例を失った. 1 例を除き 14 例 に術後 $1 \sim 3$ か月に大動脈造影を行った.

\section{結果}

\section{1. 術前解離口および解離腔}

術前大動脈造影および術中所見よりの中枢解離口は, 腕頭動脈, 左鎖骨下動脈分枝部にて大動脈を上行弓部下 行に分けると，上行（上行弓部を含む） 9 例, 弓部 2 例, 下行 3 例, 不明 1 例であった. 解離腔が上行より下 行に至るむの 13 例, 解離が上行弓部に限局するむの 2 例で，それぞれ 1 例は解離腔が造影されない血栓閉鎖型 解離であった，末梢解離口の正確な同定は困難であり全 例には検索していない.

\section{AR}

術前 $\mathrm{AR}$ を有した症例は 9 例で, $\mathrm{AR} \mathrm{I}^{\circ} 2$ 例,
$\mathbb{I}^{\circ} 3$ 例， $\mathbb{I I}^{\circ} 4$ 例である. $\mathbb{I}^{\circ}, \mathrm{II}^{\circ}$ の各 1 例に Bentall を行ったが，乙れらを含めて術後大動脈造影飞て全例 AR は消失した。

\section{3. 術後解離腔残存}

術後大動脈造影飞て, 術前より下行に解離腔の造影さ れた 11 例全例に吻合部〜弓部下行より造影される下行 解離が残存した. 血栓閉鎖型の 1 例に6手術にて切除さ れない弓部解離口よりの逆行性小解離腔が残存した.

1）吻合部求よび術後解離口

手術により切除されない弓部下行の解離口または弓部 分枝の reentry より解離腔が造影される症例は 7 例あ り, 弓部下行大動脈 6 例, 左鎖骨下動脈, 腕頭動脈の reentry 各 1 例である(腕頭動脈例は下行解離口之同一 例). このうち 3 例は解離口から吻合部にかけて逆行性 盲端腔を形成した。人工血管吻合部より解離腔が造影さ れた症例は 4 例で，乙のうち 3 例は jet 様リークを生じ た. Jet を生じた 3 例中 2 例は 2 層補強であった，術前 に認められない解離口より下行解離が造影された症例が

表 2 術後解離腔中枢

\begin{tabular}{lll}
\hline 術前よりの解離口 & 7 & \\
弓部 & & 2 \\
下行 & 4 \\
鎖下骨下動脈 (reentry) & 1 \\
腕頭動脈 (reentry) & & 1 \\
人工血管吻合部 & 4 & \\
$\quad$ jet 様リーク & 3 \\
新解離口 & 2 & \\
$\quad$ 部下行 & & 1 \\
上行弓部 & & 1 \\
\hline
\end{tabular}


19 : 1086

表 3 術後大動脈造影飞おける下行大動脈所見

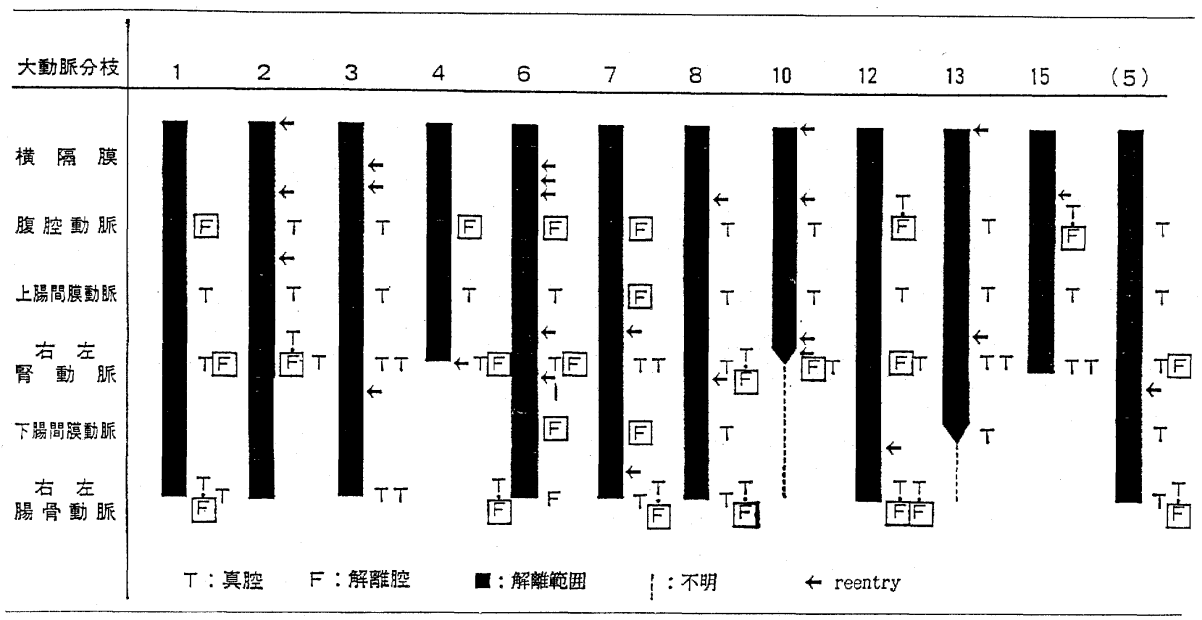

2 例あった．乙の解離口は鎖骨下動脈分岐部の弓部下行 と上行弓部前壁である.

2）腹部大動脈（剖検例を含む）

下行解離を残した 12 例と屯, 真腔と解離腔を交通す る大小の reentry を形成しつつ, 解離は腹部大動脈に 及んだ. 腹部主要分岐のうち腹腔動脈 2 例, 右腎動脈, 左腎動脈各 1 例が真腔と解離腔との両方より造影され, 腹腔動脈 4 例，上腸間膜動脈 1 例，腎動脈右 2 例，左 4 例が解離腔より造影された。

\section{3) 弓部}

術前弓部分枝に解離が及ぶ症例は 4 例で, 腕頭動脈 3 例，左銷骨下動脈 1 例である. 術後造影しえた 3 例のう 与 2 例は弓部分枝末梢の血管分岐部に reentry を形成 し，乙の reentry を中枢解離口とし，大動脈末梢の reentry を末枢解離口とする，弓部真腔を圧迫するような 大きな解離腔を形成した，他の 1 例では分枝に解離は残 存しなかった。

\section{考察}

急性 A 型大動脈解離の手術目的は上行大動脈の破裂死 の防止であり，乙の術式としてわれわれは最初の 1 例に Entry 閉銷の後, 人工血管置換を中心に行った. 術前 のARに対し Bentall 2 例行ったが, Koster 様手術に て全例 AR が消失した．このととにより AR に対する 積極的な AVR は必要でないといえる.また，下行に 解離腔の造影されるI 型症例は全例吻合部〜弓部下行よ り造影されるIII型解離が残存した. 手術により切除され ない術式解離口は当然術後も解離口として残る. 吻合部 リークが 4 例にみられたが，乙れは，急性期の解離症例
では，血管組織が脆弱であること，解離腔が固定されて いないとと，等々により吻合部にて解離腔への血流を完 全に途絶させる術式となりにくいためと考えられる，ま た，術前にない解離口の 2 例は，大腿動脈よりの送行性 貧血, clamp injury 等による術中術後の新解離口の発生 を示唆させる．乙れら中枢側より血流を生じた解離腔 は，末梢側では，真腔解離腔を交通する大小の reentry を形成し，腹部分枝を灌流する．乙のため血流が停滞し ない，乙れらが術後解離腔が残存する原因と考えられ る.

吻合部フェルト補強は中枢側は 3 層補強を原則とし, 末梢側は遮断時間を考慮して補強を行うが，2 層のほう が 3 層よりリークを生じやすい傾向にある．また，弓部 分枝に解離の及ぶ症例では，2方向の reentry になっ て交通された解離腔から弓部真腔を圧迫する形態を呈し た.

\section{結 語}

急性 $\mathrm{A}$ 型大動脈解離手術 15 例に対し術前術後の大動 脈造影を検討した，術前の AR は全側消失し，積極的 な AVR は必要でない，術中術後化解離口の新生が示 唆され, 術後む吻合部〜弓部よりの III 型解離が残存す る. とくに解離が弓部分枝に及方症例では術後む十分注 意を要する.

文 献 1) Miller, D. C. et al.: J. Thorac. Cardiovasc. Surg. 78: 365, 1979. 2) Diana, F. G. et al.: Diagn. Radiol. 133: 1, 1979. 3) Koster, J. K. et al.: Ann. Thorac. Surg. 26: 461, 1978. 